\title{
Factors Affecting the Joint Adoption of Herbicides and Conservation Tillage Technologies among Smallholder Farmers in Zambia
}

\author{
Godfrey Mutale ${ }^{1}$, Thomson Kalinda ${ }^{2} \&$ Elias Kuntashula $^{2}$ \\ ${ }^{1}$ Zambia Agricultural Research Institute, Kabwe, Zambia \\ ${ }^{2}$ Department of Agricultural Economics \& Extension, University of Zambia, Lusaka, Zambia \\ Correspondence: Elias Kuntashula, Department of Agricultural Economics \& Extension, University of Zambia, \\ Lusaka, Zambia. Tel: 260-9-6645-4366. E-mail: ekuntashula@unza.zm
}

Received: August 9, 2017

doi:10.5539/jas.v9n12p205
Accepted: September 11, $2017 \quad$ Online Published: November 15, 2017

URL: https://doi.org/10.5539/jas.v9n12p205

\begin{abstract}
For over three decades, Zambian private and public organizations have been promoting Conservation Agriculture (CA) among smallholder farmers, throughout the country. CA, as a technology, involves Conservation Tillage (CT) methods and use of herbicides, particularly in the first 3 to 4 years of its adoption. Despite the long-term CA dissemination effort from stakeholders, adoption of both herbicides and CT technologies has been relatively low. Using the 2012 Rural Agricultural Livelihood Survey (RALS12) data collected country-wide, a bivariate probit analytical model investigated whether Zambian smallholder farmers make a joint adoption decision in the uptake of herbicides and CT methods. Results indicate that the adoption of herbicides is jointly linked to the adoption of $\mathrm{CT}$ technologies. Factors such as being a male-headed household, belonging to a cooperative society, larger sizes of cultivated areas, owning productive tools such as a knapsack sprayer and receiving advice on CA technologies, were critical in positively influencing the joint-adoption of herbicide and CT technologies. Overall, results imply that if the adoption of herbicides is to be enhanced, the promotion of CT technologies have to be intensified. The best promotional channels include agricultural groups such as farmer cooperatives, which are good conduits and platforms for smallholder farmers' knowledge-sharing. These promotional efforts should support gender balancing and emphasize the inclusion and use of herbicides in CA. There is also need for government to enhance farmers' access to productive tools that support the use of herbicides such as knapsack sprayers.
\end{abstract}

Keywords: adoption, bivariate probit model, conservation agriculture, conservation tillage, herbicides, innovation, Zambia

\section{Introduction}

Agricultural challenges that Zambia is facing include climate change, food insecurity, hunger and poverty, among others (UN, 2009; FAO, 2011). Of these, hunger and poverty are the most outstanding in Sub-Saharan Africa (SSA). As a way of mitigating negative effects of climate change and ensuring food security, many stakeholders in both private and public domains, have been encouraging the adoption of Conservation Agriculture (CA) among Zambian smallholder farmers, who grow the bulk of staple foods in the country (CSO, 2014), yet have some of the lowest crop yields in the world (FARA, 2006). The adoption of crop yield-enhancing technologies by smallholder farmers is important if productivity and production among them is to be realized (Gabre-Madhin \& Johnston, 2002). Technologies like CA, if adopted, in times of climate change such as these, could guarantee national food security and reverse the ever increasing poverty among Zambian citizenry, particularly in rural areas where most of these farmers live (FAO, 2011).

According to CFU (2007), CA involves conversion from overall tillage to mechanized minimum tillage or no tillage at all. CA involve three key principles, namely; (i) the covering of soil surface through the retention of crop residues or by cropping it with living plants (ii) minimum soil movements and (iii) practicing of crop rotation involving cereals and leguminous crops. Crop rotation is practiced to reduce pest and disease build up in the fields. Essentially, CA practice involve dry-season land preparation using mechanized minimum tillage systems, crop residue retention, planting with inputs in fixed planting basins and normally include cereal/legume rotations for fixing nitrogen and thus retention of soil fertility (CFU, 2007; Hobbs, 2007). When CA is first practiced, weed infestation usually builds up owing to minimum tillage in the fields. To offset this challenge, the use of herbicides 
is initially, encouraged. It's asserted that these CA components play an important role in reducing land degradation through the efficient use of natural resources (CFU, 2007).

The emergence of CA in Zambia, occurred in late 1980s, when farmers started experiencing ecological and economical challenges. During this period, climate change became evident. Drastic rainfall patterns changes were noticed and the rains became inconsistent and irregular. Droughts and floods became more frequent. About the same time, the International Monetary Fund (IMF) and World Bank (WB) introduced free market economic structural reforms, which demanded that the government eliminates the agricultural subsidies from the sector (FAO, 2013). The occurrence of these and many related factors became influential in motivating farmers to embrace CA technologies. Starting in the early 1990s, CA technology practices became more prominent (Haggblade \& Tembo, 2003).

During this period, various organizations concerned with sustainable agricultural practices like the Soil Conservation and Agro-forestry Extension Project (SCAFE), Golden Valley Agricultural Trust (GART) among others, intensified the promotion of CA technologies Some private companies like Dunavant Cotton Ltd up marketed CA to a level where the company became obliged to train farmers in CA technology and in other CA-related agendas (Haggblade \& Tembo, 2003). In the same vein, the Government of the Republic of Zambia (GRZ), also promised to streamline farming activities among smallholder farmers so as to make CA become the farming mainstay for them. Owing to this commitment, in 1998, the Ministry of Agriculture and Co-operatives (MACO) formally acknowledged CA as an official policy in the agricultural sector (GART, 2002; MAFF, 2001). Despite these technology adoption dissemination efforts from CA promoter organizations, its adoption has remained low in Zambia. In some cases, there has been dis-adoption (Arslan et al., 2013; Philip et al., 2014). The low adoption phenomenon also applies to herbicides (Mbazima, 1997; Gianessi \& William, 2011).

Even with serious efforts exerted by stakeholders on smallholder farmers to fully adopt CA technology to mitigate climate change effects and improve crop productivity, knowledge on factors affecting adoption of CA, in general and its components such as CT and use of herbicides is scanty and unclear. Studies that were done earlier, studied CA components in isolation, as is usually the case in developing countries (Wainaina et al., 2014). For example; Mbazima (1997) studied herbicide adoption rates among small and medium scale farmers of Central and Copperbelt provinces of Zambia. A study by Philip et al. (2014) examined herbicides adoption rates of 135,000 Zambian cotton farmers by comparing the results of 2002 and 2011 censuses of cotton lead farmers and buyers. These studies focused more on adoption of single technologies and not on joint adoption of any two complementary technologies such as herbicides and CT methods under CA. Results obtained from such adoption studies may not have been robust (Green, 2003). To bridge this gap in the methodologies that were used earlier, there is need to use robust methods that take into account the simultaneity in technology adoption process, especially where technologies are promoted together, as a package, such as herbicides and CT methods in CA. Information and knowledge from a methodology that take two dependent variables and seek a simultaneous answer to adoption aspects may bring to the fore new strategies for smallholder farmers' policy formulation in CA. Such a policy could add value to accelerated food production and security in Zambia.

Given the weed infestation challenge, scarcity of labor, climate change patterns and the popular promotion of CA among smallholder farmers by many stakeholders, there is need to understand how Zambian smallholder farmers make decisions on the adoption of herbicides and conservation tillage technologies. Additionally, there is need to identify and quantify factors that affect the adoption decision process among smallholder farmers. The purpose of this study was to determine whether the farmer's adoption decisions of herbicides and CT methods, is done singularly or jointly and to identify and quantify factors affecting adoption of these technologies.

\subsection{Review of the Literature}

According to Adesina (1996), univariate models, mostly probit and logit have been used in many adoption studies in developing countries. In these models, the assumption was that before adopting a new technology, farmers first weigh the consequences of adopting such a technology against its socioeconomic and technical feasibility and assess whether the new technology sought assured them much higher utility than the one they were presently practicing (Adesina \& Zinnah, 1993). Intuitively, farmers will derive some utility from adopting either herbicides or CT or adopting the two, jointly. Whichever option gives them the highest levels of utility is likely going to be taken up. Rationality may dictate that adopting the two technologies jointly could give them more benefits/utility. Moreover, they are simultaneously promoted, so the likelihood of joint adoption is high. However, many of the papers reviewed warns of possible significant correlation of factors affecting adoption of the technologies that are simultaneously promoted (Nkamleu et al., 1999; Chirwa, 2005; Rahman, 2008; Ogada et al., 2014). This means farmers' adoption decision could be affected 
by similar but unobservable factors. This scenario may cause endogeneity bias. In this case, the modeling of adoption using single binary models such as probit or logit could give misleading results.

In South America, a few studies including that of Neill and Lee (1999) in Hondurus and De Souza Filho (1999) in Brazil found contradicting results on factors that positively affect joint adoption. Neill and Lee (1999) found that farmers' age, income from non-maize sources, accessibility to road networks and noxious weeds led to stoppage in the use of cover crops. On the other hand, diversification into high value crops and farmers' experience encouraged crop rotations (mucuna/maize). The study concluded that biological systems are dynamic and thus cannot successfully be theorized. In Brazil, De Souza Filho (1999) investigated the adoption of low-external-input and sustainable agriculture (LEISA) or otherwise using dynamic econometric framework. Results indicated that the probability of adopting LEISA increased if the farmer belonged to a farmer organization, had larger family labor, good farm soils and had regular contacts with extension services. In addition, being aware of harmful effects of inorganic inputs (fertilizers, pesticides etc.) on health and environment increased chances of LEISA adoption. The reverse was true if farm size was larger, relative prices of farm produce became lower, thus impacted negatively on farm profits. With cheaper labor in the vicinity, adoption of LEISA increased. The Brazilian study was strictly on LEISA. The country has relatively developed agricultural sector and is the most advanced in the world of CA. It has much higher crop yields/unit area than many developing countries (FARA, 2006). On the other hand, Zambia is on the lower side in terms of CA crop yields. Hence, there is need to understand factors impeding adoption of crop yield-enhancing technologies, especially among smallholder farmers, whose livelihood depend on agriculture.

In Asia, Rahman (2008) in Bangladesh and Thapa (2008) in Nepal did studies on joint adoption of agricultural technologies. Rahman studied the determinants of crop choices among Bangladesh farmers while Thapa did an adoption study between improved seed and inorganic fertilizers among Nepalese farmers. In Bangladesh, a single factor that was found to positively contribute to adoption of modern rice monoculture was availability of irrigation. Where irrigation was absent, the adoption of diversified cropping system was a priority. This was in turn impacted by other factors such as: developed infrastructure, farmers' assets, educational level, farming experience and non-farm incomes earned by farmers. Variations among regions were high in terms of adoption. On the other hand, Thapa discovered that educational level of household head, labor, farm credit and vibrant agricultural extension services were critical to joint technology adoption in Nepal. From the above studies, it can be seen that there is a variation in factors affecting joint adoption of agricultural technologies.

It must be said that not many joint adoption studies have been done in SSA. Hence, literature review on this subject matter is constrained. There are no universally established factors that can be said to be identified as critical to joint adoption of agricultural technologies, especially that many and varied technologies have been mentioned by different authors. They differ from one study to another and from one context to another. For example, being male promoted joint adoption in some studies such as that of Ogada et al. (2014) but not in others (Nkamleu et al., 1999; Chirwa, 2005). In other studies, gender played no role in the adoption process (Kassie, 2013). The educational level of household head (Nkamleu et al., 1999; Chirwa, 2005; Ogada et al., 2014) and belonging to a cooperative or credit association (Kassie, 2013; Ogada et al., 2014) contributed to joint adoption of technologies. Farm characteristics such as farm size in the case of Chirwa (2005) and asset ownership, in the case of Kassie et al. (2013) remotely supported joint adoption while distance from the commodity markets were found to negatively support joint adoption of agricultural technologies in some cases (Ogada et al., 2014). Coming to institutional factors, some studies show that contact with extension services increases the probability of joint adoption of technologies as seen in South America and Asia. However, in SSA, Kassie et al. (2013) is in support of this while the reverse is true for other studies such as that of Nkamleu et al. (1999). Land tenure is another controversial factor because it's positive in some cases (Chirwa, 2005; Kassie et al., 2013; Ogada et al., 2014) and negative in others (Nkamleu et al., 1999).

Some researchers have indicated that the characteristics of the farm itself is important in positively influencing the joint adoption of technologies (Chirwa, 2005; Zulu et al., 2008). These studies argue that good and fertile farm soils save as a motivation to farmers' increased technology adoption for an even better returns. The spatial location of a farm has been cited in positively influencing decisions to jointly adopt technologies among farmers. For example, Kizito and Thomlow (2009) in Zimbabwe, Bryan et al. (2009) in Ethiopia, Egyir (2010) in South Africa, Nkegbe et al. (2011) in Ghana and Kassie (2013) in Tanzania.

In summary, the literature that was reviewed indicated that globally, developing countries have low adoption rates of critical crop productivity-enhancing technologies, including CA technologies of which herbicides and CT 
methods are part. This observation has been acknowledged by authors such as; Gianessi and William (2011) and Abay et al. (2016). CT technologies are critical in view of the changing climate being experienced, worldwide (FAO, 2011). From the literature reviewed, many researchers in SSA have been studying factors that affect CA without linking it to herbicides with which it's, initially promoted in the first 3-4 years (FAO, 2004). This study aims at determining how smallholder farmers make decisions on the adoption of herbicides and CT methods that are jointly promoted. The study also identifies, quantifies and profiles factors that affect these adoption decisions, particularly in Zambia.

\section{Methodology}

\subsection{Data Sources}

The data used in this study came from Rural Agricultural Livelihood Survey of 2012 (RALS12) implemented by the Indaba Agricultural Policy Research Institute (IAPRI), Central Statistics Office (CSO) and Ministry of Agriculture (MA) in collaboration with Michigan State University. The survey targeted the population of $1,669,861$ Zambian smallholder farmers. This study used data on farmers who answered the questions on herbicides use and conservation agriculture. Therefore, only 8,839 cases were used.

\subsection{Data Analysis}

Stata version 11 was used for data analysis. First, descriptive statistics that summarized the main variables were computed. Secondly, correlation analysis using the chi-square test was implemented to assess the degree of association between herbicide use and the adoption of CT methods. Finally, a more robust test on the probability of joint adoption of herbicides and CT methods was implemented using a bivariate probit model.

\subsection{Bivariate Probit Model: Conceptual and Econometric Framework}

Factors that affect joint-adoption of herbicides and CT technologies were specified and examined with the assumption that smallholder farmers are rational in making adoption choices, more especially on joint-technology adoption. However, they operate in imperfect markets where there is information asymmetry. To use a univariate model approach for jointly adopted dependent variables, without proving whether they are mutually exclusive, would give erroneous results that suffer from simultaneity bias. Hence, the remedy for this problem would be a bivariate model as proposed by Maddala (1983). In a case like this, probit model is appropriate. This study aimed at exploring technology adoption decisions made by Zambian smallholder farmers in the joint-adoption of herbicides and $\mathrm{CT}$ technologies. For this reason, other non-technology variables that influence adoption decisions are treated as exogenous. In this case, the bivariate probit model is formed as a system of structural but simultaneous equations as:

$$
\begin{gathered}
h_{a d}^{*}=\alpha_{1} c t_{a d}^{*}+\beta_{1}^{\prime} \boldsymbol{Z}_{a d}+\varepsilon_{a d}^{1}, h_{a d}=1 \text { if } h_{a d}^{*}>0,0 \text { otherwise } \\
c t_{a d}^{*}=\alpha_{2} h_{a d}^{*}+\beta_{2}^{\prime} \boldsymbol{Z}_{a d}+\varepsilon_{a d}^{2}, c t_{a d}=1 \text { if } c t_{a d}^{*}>0,0 \text { otherwise } \\
\mathrm{E}\left(\varepsilon_{a d}^{1}\right)=\mathrm{E}\left(\varepsilon_{\mathrm{ad}}^{2}\right)=0, \sigma_{h}^{2}\left(\varepsilon_{a d}^{1}\right)=\sigma_{h}^{2}\left(\varepsilon_{a d}^{2}\right)=1 \text { and } \operatorname{COV}\left(\varepsilon_{a d}^{1}, \varepsilon_{a d}^{2}\right)=\rho
\end{gathered}
$$

Where, $h_{a d}^{*}$ and $c t_{a d}^{*}$ are latent dependent variables that account for the household's adoption decisions of herbicides in Equation 1 and CT technologies in Equation 2. $\boldsymbol{Z}_{a d}$ is a vector of exogenous control variables. The $\varepsilon_{a d}^{1}$ and $\varepsilon_{a d}^{2}$ are disturbance terms in each adoption equation and are distributed as standard bivariate normal variables $\left(\sigma_{i}\right)$ with the correlation coefficient, $\rho$.

From these two structural equation systems, the model has the following features:

(i) The dependent variables are binary.

(ii) The binary dependent variable in the first equation is entered into the second equation as a covariate and vice versa.

(iii) The unobserved heterogeneities of the two decisions are assumed to be linked.

Using two-stage bivariate technique, the estimates so obtained are deemed consistent and efficient (Maddala, 1983). Thus the reduced form of the model to give parametric estimates is:

$$
\begin{gathered}
h_{a d}=\partial_{1}^{\prime} \boldsymbol{Z}+e_{1} \\
c t_{a d}=\partial_{2}^{\prime} \boldsymbol{Z}+e_{2} \\
\left.\left[e_{1}, e_{2}\right] \sim B V N[0,0), \sigma_{h}^{2}, \sigma_{c t}^{2}, \tau\right]
\end{gathered}
$$

In these system of simultaneous equations, $\boldsymbol{Z}$ is a set of exogenous control variables, $\tau$ is the correlation between $e_{1}$ and $e_{2}$ disturbance terms, for herbicides and $\mathrm{CT}$ technologies, respectively. The use of this methodological procedure has been recommended by Maddala (1983). The need to account for the cross equation relationships in 
order to recover consistent estimates of the structural from reduced form of coefficients has been amply elaborated. The procedure is asymptotic and gives more efficient estimates than single equations (Maddala, 1983).

Like every discrete choice model, the coefficients of bivariate probit model are not interpreted directly, since doing so gives erroneous and misleading results. The parameters obtained are transformed into marginal effects estimates. Marginal effects are the changes in the predicted probabilities associated with the changes in the exogenous control variables depicted in the simultaneous equations. To continue with the bivariate probit model, it's necessary to establish whether or not $\rho$ is significant. In this particular case, a likelihood ratio test was done to assess whether the two error terms were significantly correlated or not.

From this bivariate model, four probabilities are identified (Greene, 1998). These are:

Probability $\left[h_{a d}=1, c t_{a d}=1\right]=B V N\left(\beta_{1}^{\prime} z_{1}+\alpha_{1}, \beta_{2}^{\prime} z_{2}+\alpha_{2}, \rho\right)$

Where, $B V N$ is the bivariate normal cumulative distribution function. Using the same analogy, other probabilities are deduced:

Probability $\left[h_{a d}=0, c t_{a d}=1\right]=B V N\left(-\beta_{1}^{\prime} z_{1}-\alpha_{1}, \beta_{2}^{\prime} z_{2}, \rho\right)$

Probability $\left[h_{a d}=1, c t_{a d}=0\right]=B V N\left(\beta_{1}^{\prime} z_{1}, \beta_{2}^{\prime} z_{2},-\rho\right)$

Probability $\left[h_{a d}=0, c t_{a d}=0\right]=B V N\left(-\beta_{1}^{\prime} z_{1},-\beta_{2}^{\prime} z_{2}, \rho\right)$

The marginal effects in this binary model are:

$$
\mathrm{E}\left[h \mid z_{i}\right]=\Phi\left(\beta^{\prime} z_{i}\right)=\operatorname{Prob}[h=1]
$$

Thus for a continuous variable, $X_{i}$, then:

$$
\frac{\partial \mathrm{E}\left[h \mid z_{i}\right]}{\partial X_{i}}=\partial \Phi\left(\beta^{\prime} z_{i}\right) / \partial X_{i}=\varnothing\left(\beta^{\prime} z_{i}\right) \beta_{x}
$$

Where, $\varnothing($.$) is the standard normal distribution and \beta_{x}$ is the coefficient of the variable. So for $X_{i}$, which is a binary variable, it is formulated as:

$$
\frac{\partial \mathrm{E}\left[h \mid z_{i}\right]}{\partial X_{i}}=\mathrm{E}\left[h \mid z_{i}=1\right]-\mathrm{E}\left[h \mid z_{i}=0\right]
$$

The marginal effect for herbicide adoption is written as:

$$
\begin{gathered}
\frac{\partial B V N\left[\Phi\left(\beta_{1}^{\prime} z_{1}+\alpha_{1}, \beta_{2}^{\prime} z_{2}+\alpha_{2}, \rho\right)\right]}{\partial X_{k}}= \\
\left\{\Phi\left(\beta_{1}^{\prime} z_{1}+\alpha_{1}\right) \Phi\left[\left(\alpha_{2} z_{2}-\rho\left(\beta_{1}^{\prime} z_{1}+\alpha_{1}\right)\right) / \sqrt{1-\rho^{2}}\right]\right\} \beta_{x}+\left\{\Phi\left(\alpha_{2} z_{2}\right) \Phi\left[\left(\beta_{1}^{\prime} z_{1}+\alpha_{1}-\rho\left(\alpha_{2} z_{2}\right)\right) / \sqrt{1-\rho^{2}}\right]\right\} \alpha_{x}
\end{gathered}
$$

In the same way, the marginal effect for $\mathrm{CT}$ technology adoption is written as:

$$
\begin{gathered}
\frac{\partial B V N\left[\Phi\left(\beta_{2}^{\prime} z_{2}+\alpha_{2}, \beta_{1}^{\prime} z_{1}+\alpha_{1}, \rho\right)\right]}{\partial X_{k}}= \\
\left\{\Phi\left(\beta^{\prime} z_{2}+\alpha_{2}\right) \Phi\left[\left(\alpha_{1} z_{1}-\rho\left(\beta_{2}^{\prime} z_{2}+\alpha_{2}\right)\right) / \sqrt{1-\rho^{2}}\right]\right\} \beta_{x}+\left\{\Phi\left(\alpha_{1} z_{1}\right) \Phi\left[\left(\beta_{2}^{\prime} z_{2}+\alpha_{2}-\rho\left(\alpha_{1} z_{1}\right)\right) / \sqrt{1-\rho^{2}}\right]\right\} \alpha_{x}
\end{gathered}
$$

When there is correlation between errors of the bivariate dependent variables, then, $\rho=0$. Once this is so, the entire expression reduces to:

$$
\Phi\left(\beta_{2}^{\prime} z_{2}\right) \Phi\left(\beta^{\prime} z_{1}+\alpha_{1}\right)+\Phi\left(-\alpha_{2} z_{2}\right) \Phi\left(\beta_{1}^{\prime} x_{1}\right)
$$

From econometric theory, the distribution of $h$ and $c t$ are independent if and only if $\rho=0$.

\subsection{Empirical Model Specification}

The underlying motivation driving smallholder farmers' decision to adopt herbicide use and/or CT technologies, is unobservable. What is observed are the farmers' choices, which are either a farmer adopts the technologies or does not. For this reason, only a latent model (an index function) is the suitable model for their exploration. This study used bivariate probit model to overcome the inadequacies of a univariate model. For the farmer, the decision "to adopt herbicides and/or CT technologies" in his crop farming activities or "not to adopt" any, means the dependent (response) variable is bivariate. This means, it takes the value 1, if a farmer adopts the use of herbicides and/or CT method. On the contrary, if the farmer decides not to adopt the use of either, then the Response variable assumes the value of 0 . The independent variables are those which are hypothesized to have association with the dissemination and adoption of one or both technologies of interest. The potential explanatory variables, which are hypothesized to influence the adoption of these technologies by smallholder farmers in Zambia are presented in Table 1. 
By implication, a bivariate probit model has four probable outcomes, namely:

(i) the adoption of both herbicide and conservation tillage technology $(h=1, c t=1)$

(ii) the adoption of herbicide technology only $(h=1, c t=0)$

(iii) the adoption of conservation tillage technology only $(h=0, c t=1)$

(iv) the non-adoption of both herbicides and conservation tillage $(h=0, c t=0)$

The dependent variable represents the observed binary outcomes that reveal optimal utility derived from adoption of herbicides and/or CT. The interactions of independent variables may result in any one of the four possible outcomes discussed in (i) to (iv) above.

\subsection{Hypothesized Factors Influencing Adoption of Crop Herbicides and CT Technologies}

Smallholder farmers' decisions to jointly adopt agricultural technologies are affected by a number of factors, as outlined in the literature review (Nkamleu \& Adesina, 1999; Rahman, 2008; Ngoma et al., 2012; Thapa, 2008; Ogada et al., 2014; Wainaina et al., 2014). In this study, variables that were picked for inclusion in this research are those which are regularly cited in literature. Based on this criterion, Table 1 outlines the variables pertinent to this study. In Table 1, the description of each variable is followed by the expected impact on farmers' decision to adopt herbicides and/or CT methods. The variables have been classified into four broad categories. The first is the farmers' characteristics, the second is the farm characteristics, institutional support system is the third and the fourth and last one is the spatial location of the farm. 
Table 1. Definition of variables used in the biprobit model

\begin{tabular}{|c|c|c|}
\hline Variable name & Description and type of variable & Expected impact \\
\hline \multicolumn{3}{|l|}{ Dependent variable } \\
\hline \multirow{4}{*}{$\begin{array}{l}\text { Adoption of crop Herbicides and/or } \\
\text { Conservation Tillage }\end{array}$} & Non-adoption of both herbicides and CT $(\mathrm{h}=0, \mathrm{ct}=0)$ & \\
\hline & Adoption of herbicide technology only $(\mathrm{h}=1, \mathrm{ct}=0)$ & \\
\hline & Adoption of conservation tillage technology only $(\mathrm{h}=0, \mathrm{ct}=1)$ & \\
\hline & Adoption of both herbicide and conservation tillage technology $(\mathrm{h}=1, \mathrm{ct}=1)$ & \\
\hline \multicolumn{3}{|l|}{ Independent variables } \\
\hline \multicolumn{3}{|l|}{ 1. Farmer Household Characteristics } \\
\hline Farmer's Age & Economically active period of respondent farmer (15-59 yrs) & $+/-$ \\
\hline Gender of Household head & Male headed Household ( $=1$, if male, $0 \mathrm{o} / \mathrm{w}$ ) & $+/-$ \\
\hline No formal of education & No formal education & Base category \\
\hline Primary education & Primary education dummy (attended $=1,0$ otherwise) & $+/-$ \\
\hline Basic education dummy & Basic education dummy(attended $=1,0$ otherwise $)$ & + \\
\hline Secondary education dummy & Secondary education (attended $=1,0$ otherwise) & + \\
\hline College education dummy & College education (attended $=1,0$ otherwise) & + \\
\hline University education dummy & University education (attended $=1,0$ otherwise) & + \\
\hline Member of cooperative society & Member of cooperative society $($ member $=1,00 / w)$ & + \\
\hline Member of credit association & Member of credit association $($ member $=1,00 / w)$ & + \\
\hline \multicolumn{3}{|l|}{ 2. Farm Characteristics } \\
\hline Number of household members & Number of people in the household & + \\
\hline Crops planted in a season & The number of crops panted per season & + \\
\hline Area/Hectares planted & The number of hectares planted in a season & $+/-$ \\
\hline Owning a knapsack sprayer dummy & Owning a knapsack sprayer (owning $=1,0$ otherwise) & + \\
\hline Owning livestock dummy & Owning livestock (owning $=1,0$ otherwise) & $+/-$ \\
\hline Tillage method & Tillage method (CA tillage method $=1,0 \mathrm{o} / \mathrm{w})$ & $+/-$ \\
\hline Distance to extension officer & Distance to extension officer $(\mathrm{km})$ & $+/-$ \\
\hline Distance to nearest Agro-dealer & Distance to nearest Agro-dealer $(\mathrm{km})$ & $+/-$ \\
\hline Distance to nearest town center & Distance the nearest to the nearest town center $(\mathrm{km})$ & $+/-$ \\
\hline \multicolumn{3}{|l|}{ 3. Institutional Factors } \\
\hline Land tenure & Land tenure(if secure $=1,0$ otherwise) & $+/-$ \\
\hline Receive CA advice dummy & Household receive advice on $\mathrm{CA}($ receive $=1,0 \mathrm{o} / \mathrm{w})$ & + \\
\hline MAL extension services & Household receive MAL Extension services (receive $=1,0 \mathrm{o} / \mathrm{w}$ ) & + \\
\hline Pvt Co. extension services & Household receive Private Co. Extension Services (receive $=1,0 \mathrm{o} / \mathrm{w}$ ) & + \\
\hline NGO extension services & Household receive NGO extension services (receive $=1,0 \mathrm{o} / \mathrm{w}$ ) & + \\
\hline \multicolumn{3}{|l|}{ 4. Location of the Farm } \\
\hline Central province & Province where SHF farm is. $($ Central $=1,0 \mathrm{o} / \mathrm{w})$ & $+/-$ \\
\hline Copperbelt province & Province where SHF farm is. $($ Copperbelt $=1,00 / w)$ & $+/-$ \\
\hline Eastern province & Province where SHF farm is. $($ Eastern $=1,00 / w)$ & $+/-$ \\
\hline Luapula province & Province where SHF farm is. (Luapula $=1,00 / \mathrm{w}$ ) & $+/-$ \\
\hline Lusaka province & Province where SHF farm is. (Lusaka $=1,0$ 0/w) & $+/-$ \\
\hline Muchinga province & Province where SHF farm is. (Muchinga $=1,00 / w$ ) & $+/-$ \\
\hline Northern province & Province where SHF farm is. (Northern $=1,0$ 0/w) & $+/-$ \\
\hline North-western province & Province where SHF farm is. (Base Province) & Base Province. \\
\hline Southern province & Province where SHF farm is. (Southern $=1,00 / \mathrm{w}$ ) & $+/-$ \\
\hline Western province & Province where SHF farm is. (Western $=1,00 / w)$ & $+/-$ \\
\hline
\end{tabular}

Source: IAPRI/CSO RALS12 survey data.

\subsubsection{Farmer Household Characteristics}

The role of age in agricultural technology adoption has been found to be varying. Normally, the age of the household head has been used as a proxy for farming experience, hence inspire joint adoption of technologies by 
the older, compared to younger farmers (Egyir, 2010; Beltran et al., 2013). However, Uwaegbuonu (2010) found otherwise. In the latter case, the study found that younger farmers were more willing to adopt new technology for longer-term productivity than otherwise. Owing to this contradiction, apriori age is assumed indeterminate.

Household characteristics such as gender, level of education and being a member of a credit association or a cooperative society also affect the decision to jointly adopt herbicides and CT methods (Table 1). Female headed households, for example, may not be eager to adopt new technologies jointly or singularly compared to male headed households. This may be due to cultural factors or differences in resource endowments (Kassie et al., 2012). The assertion that female-headed households usually have less access rights to productive assets/tools than do male-headed counterparts has been highlighted in literature (Beltran et al., 2013; Government of Canada, 2013) On the other hand, however, females are more involved in small-scale farming activities than males (FAO, 1996). Owing to this ambiguity, the effect of gender on adoption of crop herbicides and/or CT, may take either sign.

\subsubsection{Farm Characteristics}

With increasing household size, family labor supply increases and so is the probability of adoption of jointly-promoted technologies. For smallholder farmers, household size determines the amount of labor supply for their farm (Haggblade \& Tembo, 2003; Nyanga et al., 2011). Larger farm households are more capable of providing the necessary labor that a new technology may demand, especially during peak periods such as at land preparation and at weeding (for herbicide application). Hence, the household size is assumed positive for the adoption of either or both technologies (Chikoye, 2004; Mohammad, 2004; Gianessi \& William, 2011; Government of Canada, 2013).

Other important aspects such as ownership of knapsack sprayer, which is a productive tool is expected to improve joint adoption of herbicides and CT methods. Owning a sprayer is capable of making herbicide application faster and easier compared to hiring or not having one. Ngoma (2010) reported that with the sustained supply of herbicides in user-friendly packages for smallholder farmers, who know how to operate knapsack sprayers, it was easier and faster to adopt the herbicide technology. Hence, even CT technologies as they move together.

The more number of crops planted per season, the more farming capability and capacity that the household has because it uses more of the scarce resources (such as; land, time and variable inputs). For these reasons, a positive sign is assigned to this variable. The same argument follows the size of the field cultivated and planted (area planted). However, larger fields entail limitation on field operations' timing and a huge demand on labor resource. Hence, a household with larger family size is more likely to adopt a new technology, to offset for the hindrances on capacity of farm operations. New technology will assist in the efficiency and timely field operations and improve farm productivity (Chikoye, 2004; Mohammad, 2004). CT methods conserve soil structure and promote soil productivity (CFU, 2007). Hence, the sign for these two variables is positive.

\subsubsection{Institutional Factors}

Access to extension services, is an important source of information on farming practices and new agricultural technologies. Before farmers decide to adopt any potential technology, they become well-informed about the potential benefits or otherwise (Rodolfo, 1996; Nkamleu et al., 1999; Tecklewold et al., 2000; Nkegbe et al., 2011). The more contact times the farmer gets from extension services through private, public, NGOs or any media, the more well-informed he becomes about latest technologies and the high the chances of adoption of the technology in question (Kalineza et al., 1999; Egyir, 2010; Ngoma, 2010). Owing to the frequency with which access to extension services has been quoted and the impact it has shown in earlier work, it has been assigned a positive sign.

\subsubsection{Location of a Farm}

Climatic conditions, inherent soils fertility, local micro-economy and other factors vary across different agro-ecological zones in Zambia. Variations in locations imply differences in farmers' perceptions on the adoption of these two technologies and consequently, their decisions to adopt their use. The importance of farm location, as a variable in technology adoption, has been hinted by authors such as Rahman (2008) and Bryan et al. (2009) as bordering on micro-economics and market access.

\subsection{Statistical Tests and Specification Issues}

The main problems in cross sectional data are heteroscedasticity and multicolinearity. To ensure consistency in the data, tests for these two data problems were done. To account for heteroscedasticity, a "robust" bivariate probit regression was done using Stata 11 software. The robust option takes care of heteroscedasticity by adjusting the standard errors (Baum, 2006). As for multicolinearity, the software takes care of this by dropping all variables that 
are correlated, except for one, which it takes into the regression. In this study, two variables had this problem, namely; university and college education dummies. Considering that university education was negligible, it was combined with the college to end up with one variable recoded as university/college. This is the variable that entered the analysis and was consistent with the study objectives. To ensure compliance with multicolinearity, its test was done using vif (Variance Inflation Factor) option in Stata 11. All runs of predictor variables yielded vif values below 10. This was a confirmation that multicolinearity problem was ably controlled and there was no problem between any two or more covariates that were used in the analysis.

\section{Results and Discussion}

\subsection{Descriptive Statistics of the Characteristics of Smallholder Farmers of Zambia}

Table 2 below depicts the descriptive statistics of the whole sample, herbicide and CT technology adopters and their associated non-adopter categories. The characteristics affecting adoption of herbicide and/or conservation tillage by Zambian smallholder farmers have been classified into four broad categories, namely: farmer characteristics, farm characteristics, institutional factors and the farmers' agro-ecological location of the farm.

In the last two columns of Table 2, a one-way analysis of variance (ANOVA 1) using Generalized Linear Model (GLM) was used to, preliminarily, test the significance of the variations across categories. The table depicts significant differences among categories in several hypothesized variables.

Results (Table 2) show that only 482 smallholder farmers adopted the use of herbicides. This means the adoption rate of herbicide in 2012 was 5.45\%. This is similar to the figure Mbazima (1997) found (5.5\%) in 1997. It's also similar to that of Gianessi and William (2011), who found the adoption to be just below 5\% in the developing countries of Africa. For Zambia, these results suggest that the rate of herbicide adoption among smallholder farmers has remained almost constant since 1997.

Out of 8,839 farmers, only 288 adopted CT tillage methods representing an adoption rate of $3.26 \%$. The low adoption rates of CT methods in Zambia have been reported elsewhere (FAO, 2013; Gianessi, 2011; Knowler et al., 2007; Ngoma et al., 2012). Within these adoption percentages are those farmers, who jointly adopted both technologies. They account for only $0.78 \%$ of the sample. Going by the figures in Table2, farmers are more likely to adopt herbicides as the priority technology, followed by CT methods. Notwithstanding these results, literature showed that herbicide and CT technology adoption is still low in this country and the rest of developing countries (Beltran et al., 2013; Gianessi \& William, 2011).

The farmer household characteristics in Table 2 suggest that over $80 \%$ of smallholder farm households are male-headed. This result is consistent with the findings of other earlier studies (CSO, 2010; Rahman et al., 2010). The joint adopter category was found to have more economically active members, aged between 15 and 59 years, in their households. The average number of economically active household members was higher at 3.58 compared to any other adopter category. This result indicates that with more economically-active household members, the possibility of having more productive labor increases. Hence, the joint-adoption of technology also increased. This has been found to be so in several other earlier studies (Nkamleu \& Adessina, 1999; Arslan et al., 2013).

In the sample, about $88 \%$ of smallholder farmers had some formal education. The overall formal educational distribution was that $57 \%$ of the household heads reached primary level, $16.6 \%$ reached basic education while $14.3 \%$ had attained secondary education. Only $0.78 \%$ received tertiary education. Within this, the component of those that had University education was only $0.12 \%$. For Zambia, this outcome supports the findings of CSO (2006). This kind of education distribution has been observed in many earlier studies in Africa (Nzomoi, 2007; Chikoye et al., 2007b; Egyir, 2010; Gianessi et al., 2011).

Membership to a cooperative society was higher among all technology adopters' categories than that of non-adopter counterparts. The mean cooperative membership for herbicide and CT adopters was $65.4 \%$ and $57.3 \%$, respectively, while that of a typical smallholder farmer was only $45.1 \%$. For joint-adopters, the proportion of farmers with membership to cooperatives was even higher at $72.5 \%$. These statistics suggest that belonging to a cooperative has a strong positive influence on technology adoption. For the joint technology adoption, results of this nature have been discovered in earlier studies (Nkegbe et al., 2011). 
Table 2. Summary statistics of the characteristics of Zambia's smallholder farmers by herbicides and CT technologies adoption status

\begin{tabular}{|c|c|c|c|c|c|c|c|c|c|c|c|c|c|c|}
\hline \multirow{3}{*}{ Variable Names } & \multirow{2}{*}{\multicolumn{2}{|c|}{ Whole Sample }} & \multicolumn{4}{|c|}{ Herbicides } & \multicolumn{4}{|c|}{ Conservation Tillage } & \multirow{2}{*}{\multicolumn{2}{|c|}{$\begin{array}{l}\text { Joint Adopters } \\
(\mathrm{h}=1, \mathrm{ct}=1)\end{array}$}} & \multirow{3}{*}{$\begin{array}{l}\text { F-test }^{\alpha} \\
\text { Across } \\
\text { categories } \\
\text { (ANOVA 1) }\end{array}$} & \multirow{3}{*}{ Sign. Lev. } \\
\hline & & & \multicolumn{2}{|c|}{$\begin{array}{l}\text { Adopters } \\
(\mathrm{h}=1, \mathrm{ct}=0)\end{array}$} & \multicolumn{2}{|c|}{ Non-Adopters } & \multicolumn{2}{|c|}{$\begin{array}{l}\text { Adopters } \\
(\mathrm{h}=0, \mathrm{ct}=1)\end{array}$} & \multicolumn{2}{|c|}{ Non-Adopters } & & & & \\
\hline & Mean & Std. Dev. & Mean & Std. Dev. & Mean & Std. Dev. & Mean & Std. Dev. & Mean & Std. Dev. & Mean & Std. Dev. & & \\
\hline \multicolumn{15}{|c|}{ 1. Farmer Household Characteristics } \\
\hline Age from 15-59 (years) & 2.845 & 1.633 & 3.340 & 1.808 & 2.816 & 1.618 & 3.045 & 1.787 & 2.838 & 1.627 & 3.580 & 1.547 & 3.37 & $* * *$ \\
\hline No Formal Education & 0.117 & 0.321 & 0.093 & 0.291 & 0.118 & 0.323 & 0.080 & 0.272 & 0.118 & 0.323 & 0.044 & 0.205 & 5.86 & $* *$ \\
\hline Pri_schl (0-7 schl yrs) & 0.567 & 0.496 & 0.456 & 0.499 & 0.574 & 0.495 & 0.615 & 0.488 & 0.566 & 0.496 & 0.464 & 0.502 & 2.23 & ns \\
\hline Sec_schl $(8-12$ schl yrs $)$ & 0.272 & 0.445 & 0.361 & 0.481 & 0.267 & 0.442 & 0.247 & 0.432 & 0.273 & 0.445 & 0.348 & 0.480 & 3.06 & $*$ \\
\hline Univ/Col (> 13 yrs) & 0.001 & 0.035 & 0.008 & 0.091 & 0.001 & 0.029 & 0.000 & 0.000 & 0.001 & 0.036 & 0.000 & 0.000 & 11.03 & $* * *$ \\
\hline Member of a Cooperative & 0.451 & 0.498 & 0.654 & 0.476 & 0.439 & 0.496 & 0.573 & 0.496 & 0.447 & 0.497 & 0.725 & 0.450 & 64.81 & $* * *$ \\
\hline Member of Credit Assoc. & 0.033 & 0.177 & 0.060 & 0.238 & 0.031 & 0.173 & 0.059 & 0.236 & 0.032 & 0.175 & 0.116 & 0.323 & 15.45 & $* * *$ \\
\hline \multicolumn{15}{|l|}{ 2. Farm Characteristics } \\
\hline Household Size (No.) & 5.849 & 2.673 & 6.595 & 2.861 & 5.806 & 2.655 & 6.146 & 2.899 & 5.839 & 2.664 & 6.812 & 2.309 & 2.98 & $* * *$ \\
\hline Tillage Method & 0.033 & 0.178 & 0.143 & 0.351 & 0.026 & 0.160 & 1.000 & 0.000 & 0.000 & 0.000 & 1.000 & 0.000 & 23189.41 & $* * *$ \\
\hline Herbicide_spray & 0.055 & 0.227 & 1.000 & 0.000 & 0.000 & 0.000 & 0.240 & 0.428 & 0.048 & 0.214 & 1.000 & 0.000 & 5806.75 & $* * *$ \\
\hline No. Crops Planted & 2.583 & 1.522 & 3.257 & 1.537 & 2.544 & 1.512 & 3.379 & 1.562 & 2.556 & 1.514 & 3.391 & 1.665 & 12.01 & $* * *$ \\
\hline Ha_(Area planted) & 2.047 & 2.246 & 3.607 & 2.981 & 1.957 & 2.162 & 2.639 & 2.196 & 2.027 & 2.245 & 3.502 & 2.726 & $\mathrm{~F} \gg>$ & $* * *$ \\
\hline Own Sprayer (knapsack) & 0.146 & 0.353 & 0.425 & 0.495 & 0.130 & 0.336 & 0.309 & 0.463 & 0.140 & 0.347 & 0.536 & 0.502 & 251.9 & $* * *$ \\
\hline Own Cattle & 0.306 & 0.461 & 0.438 & 0.497 & 0.298 & 0.458 & 0.318 & 0.467 & 0.306 & 0.461 & 0.431 & 0.499 & 11.7 & $* * *$ \\
\hline Dist to Town Center (km) & 40.57 & 33.10 & 35.58 & 24.80 & 40.86 & 33.41 & 34.23 & 24.04 & 40.79 & 33.26 & 31.10 & 22.62 & 0.81 & ns \\
\hline Dist to Agro Dealer (km) & 32.99 & 29.94 & 28.40 & 30.70 & 33.26 & 29.88 & 27.09 & 22.88 & 33.19 & 30.13 & 19.36 & 13.76 & 0.92 & ns \\
\hline Dist to Extension Off $(\mathrm{km})$ & 19.68 & 24.34 & 17.82 & 19.09 & 19.79 & 24.61 & 15.67 & 18.33 & 19.82 & 24.51 & 15.31 & 13.60 & 0.82 & $\mathrm{~ns}$ \\
\hline \multicolumn{15}{|l|}{ 3. Institutional Factors } \\
\hline $\begin{array}{l}\text { Land Tenure } \\
(\mathrm{s}=1,0=\mathrm{o} / \mathrm{w})\end{array}$ & 0.092 & 0.289 & 0.131 & 0.337 & 0.090 & 0.286 & 0.076 & 0.266 & 0.093 & 0.290 & 0.159 & 0.369 & 0.83 & $\mathrm{~ns}$ \\
\hline $\begin{array}{l}\text { CA Advce } \\
(\text { yes }=1,0=\mathrm{o} / \mathrm{w})\end{array}$ & 0.550 & 0.498 & 0.734 & 0.442 & 0.539 & 0.499 & 0.660 & 0.475 & 0.546 & 0.498 & 0.812 & 0.394 & 52.92 & $* * *$ \\
\hline Import_CA info .supplier & 1.467 & 0.778 & 1.546 & 0.776 & 1.463 & 0.778 & 1.454 & 0.742 & 1.468 & 0.779 & 1.546 & 0.768 & 12.02 & $* * *$ \\
\hline \multicolumn{15}{|l|}{ 4. Location of the Farm } \\
\hline North-west Province $(=0)$ & 0.072 & 0.259 & 0.008 & 0.091 & 0.076 & 0.265 & 0.007 & 0.083 & 0.075 & 0.263 & 0.015 & 0.120 & 41.01 & $* * *$ \\
\hline Central $(=1,0=\mathrm{o} / \mathrm{w})$ & 0.095 & 0.293 & 0.178 & 0.383 & 0.090 & 0.287 & 0.139 & 0.346 & 0.094 & 0.291 & 0.174 & 0.382 & 29.81 & $* * *$ \\
\hline Copperbelt $(=1,0=\mathrm{o} / \mathrm{w})$ & 0.077 & 0.267 & 0.141 & 0.349 & 0.073 & 0.261 & 0.066 & 0.249 & 0.077 & 0.267 & 0.130 & 0.339 & 5.36 & $* *$ \\
\hline Eastern $(=1,0=\mathrm{o} / \mathrm{w})$ & 0.226 & 0.418 & 0.284 & 0.452 & 0.223 & 0.416 & 0.326 & 0.470 & 0.223 & 0.416 & 0.188 & 0.394 & 22.59 & $* * *$ \\
\hline Luapula $(=1,0=\mathrm{o} / \mathrm{w})$ & 0.095 & 0.293 & 0.044 & 0.204 & 0.098 & 0.297 & 0.052 & 0.223 & 0.097 & 0.295 & 0.073 & 0.261 & 15.30 & $* * *$ \\
\hline Lusaka $(=1,0=\mathrm{o} / \mathrm{w})$ & 0.041 & 0.198 & 0.069 & 0.253 & 0.039 & 0.194 & 0.076 & 0.266 & 0.040 & 0.195 & 0.145 & 0.355 & 15.48 & $* * *$ \\
\hline Northern $(=1,0=\mathrm{o} / \mathrm{w})$ & 0.077 & 0.267 & 0.087 & 0.282 & 0.076 & 0.266 & 0.129 & 0.335 & 0.075 & 0.264 & 0.130 & 0.339 & 10.31 & $* * *$ \\
\hline Muchinga $(=1,0=\mathrm{o} / \mathrm{w})$ & 0.113 & 0.317 & 0.029 & 0.168 & 0.118 & 0.323 & 0.097 & 0.297 & 0.114 & 0.317 & 0.015 & 0.120 & 14.15 & $* * *$ \\
\hline Southern $(=1,0=\mathrm{o} / \mathrm{w})$ & 0.118 & 0.322 & 0.108 & 0.311 & 0.118 & 0.323 & 0.080 & 0.272 & 0.119 & 0.324 & 0.087 & 0.284 & 3.88 & $* *$ \\
\hline Western $(=1,0=\mathrm{o} / \mathrm{w})$ & 0.086 & 0.280 & 0.052 & 0.222 & 0.088 & 0.283 & 0.028 & 0.165 & 0.088 & 0.283 & 0.044 & 0.205 & 18.59 & $* * *$ \\
\hline No. of Observations & 8839 & & 482 & & 8357 & & 288 & & 8551 & & 69 & & & \\
\hline
\end{tabular}

Note. Significance levels: $\mathrm{p} \leq 1 \%=* * *, \mathrm{p} \leq 5 \%=* *, \mathrm{p} \leq 10 \%=*$, ns $=$ non-significant result.

F-test $^{\alpha}=$ One-way ANOVA using GLM.

Table 2 shows that Zambian smallholder farmers' average number of household members' hovers around 5 to 6 (specifically 5.85). For joint-adopters, this was slightly higher at 6.81. For individual technology adopters, household size was just below that of joint adopter category. For herbicide adopters, it was 6.59 , while that of CT technology adopters was 6.14 . This result suggests that the joint adoption decision of technology was more linked to larger household sizes. La Rovere et al. (2000) and Zulu et al. (2008) found similar results in their work.

For the number of crops planted, results suggest that technology adopters plant more crops per unit area than non-adopters. Overall, however, joint-technology adopter farmers planted about 3.5 crops per season compared to only 2.6 crops by non-technology adopter farmers. As for area planted, joint-technology adopters planted about 3.5 
ha per season compared to only 2.0 ha for non-adopter farmers. These aspects have been highlighted in literature as bordering on labor availability and flexibility in operations when household labor was available at farm stead (Chikoye et al., 2004; Mohammad, 2004; Egyir, 2010; Gianessi et al., 2011; Beltran et al., 2011; Government of Canada, 2013).

The percentage of farmers who owned knapsack sprayers and jointly adopted herbicide and CT technologies was $53.6 \%$ compared with $14.6 \%$ of a typical smallholder farmer. Given the connection between farm productivity and owning farm productive tools, like a knapsack sprayer, by a smallholder farmer, proved that it had a profound impact on adoption of either or both technologies. Earlier studies in Zambia by Ngoma (2010) and in Philippines by Beltran et al. (2011) found a similar outcome.

Tillage methods also differed across adopter categories. The average adoption of CT in the whole sample was at $3.3 \%$, while the CT adoption rate by farmers who also adopted herbicides was $14.3 \%$. For non-adopters of herbicide technology, it was only $2.6 \%$ (Table 2 ). This outcome has shown that the more the herbicide adoption, the more likely that CT technologies will also be adopted. In general, results suggest that the promotion of one, stimulates the promotion of the other. Nyanga (2011) and Haggblade et al. (2004) found identical results in the earlier work involving these technologies.

Results indicate that technology adopters were closer to service providers than did the non-adopters. For example, joint adopters of herbicides and CT methods were within $19 \mathrm{~km}$ from agro-dealers, while non-adopters were about $33 \mathrm{~km}$ away, on average. Longer distances to service providers such as agro-dealers and extension services proved to be a disincentive to adoption of these technologies. This research verifies results obtained in earlier studies by other authors such as Nkamleu et al. (1999) and Nkegbe (2011).

CA information reception results show that there is a variation in adoption levels according to the technology adoption category. Table 2 shows that $81.2 \%$ of joint adopter farmers received CA advice and information while only $73.4 \%$ of herbicide adopters did so. As for CT adopters only $66.0 \%$ received CA advice. The government's important role in providing extension services for quick technology adoption has been acknowledged in many earlier studies (Kalineza et al., 1999; Nzomoi, 2007; Ngoma, 2010; Egyir, 2010). The fact that a higher percentage of farmers who adopted the technologies also had more extension service contacts show that extension is a catalyst to farmer awareness and eventual adoption of improved technologies. In this study, the role played by information assimilation is underpinned by the number of farmers adopting the new technology after being in constant contact with information providers.

Farm location proved to be a critical factor in technology adoption. Results indicate that farmers in more urbanized provinces have higher concentration of joint-technology adoption than those in rural setting. The same trend and pattern characterize the singularly adopted technologies. Eastern province appears to break the pattern in that smallholder farmers in Eastern province have the highest joint-adoption rate beating the urbanized provinces like Copperbelt and Lusaka. The greater information exposure the province has been receiving over the years compared to other provinces may have been responsible for this result. In fact, Arslan et al. (2013) noted the same trend. For the rest of the more urbanized areas like Central, Copperbelt and Lusaka, this adoption impact pattern may have to do with institutional and infrastructural development and accessibility to commodity markets. The nearer a farmer is to the potential market, the more the motivation to be agriculturally productive for commercial reasons and vice versa.

\subsection{Joint Decision to Adopt Herbicides and Conservation Tillage}

The Chi-square correlation analysis between herbicides and CT technologies adoption was found to be highly significant $\left(\chi^{2}=197.7, d f=1, p=0.000\right)$, showing that there is a relationship between the adoption of herbicides and the practice of conservation tillage among smallholder farmers. This result suggests that smallholder farmers who adopt conservation tillage are also likely to adopt the use of herbicides.

A more robust likelihood ratio test (LR) from the bi-variate probit model $\left(r h o=0, \chi^{2}=66.6, p=0.0000\right)$ showed that these two technologies' adoption process is jointly determined. This implies that the two error terms between the adoption of herbicides and the practice of conservation tillage are significantly correlated. In other words, the unobserved and thus unmeasured factors affecting adoption of the two technologies are similar. For this reason, the herbicide and CT adoption can robustly be analyzed as a joint decision making process.

The actual numbers of farmers who jointly adopted both herbicide and CT methods was low. Only 69 out of a sample of 8,839 adopted the technologies jointly (Table 2). This represents $0.78 \%$ of the sample. Essentially, this means that technologies responsible for enhancing higher and improved crop yields, such as jointly adopting herbicides and CT methods are still low among smallholder farmers, who produce most of the staple foods in 
Zambia (CSO, 2010). On the other hand, farmers who adopted herbicides technology only were 413, accounting for $4.67 \%$. Those who adopted CT technologies were 219 , accounting for $2.48 \%$ of the total. These statistics denotes that very few farm households with more members of economically active age group, have higher chances of jointly adopting herbicides and $\mathrm{CT}$ technologies (Table 2). This partly explains the persistent food insecurity experienced in the country and in the region. FAO (2009) and Arslan et al. (2013) obtained similar results on adoption decisions among smallholder farmers.

\subsection{Factors Determining the Joint-Adoption Decisions of Crop Herbicides and Conservation Tillage by Smallholder Farmers in Zambia}

Table 3 below shows estimates and the marginal effects of smallholder farmers' characteristics, farm characteristics, institutional factors and the agro-ecological location of farm households on the joint-decision of herbicides and $\mathrm{CT}$ technologies. For the purposes of general comparison, the joint-adoption decision model is laid side by side with separate individual models of adoption of either herbicides or CT technologies. However, only the robust joint-decision model results are discussed in details. In the case of agro-ecological location of farm households, Northwestern province was set as the base category. This is because it accounted for the lowest contribution to the adoption of both herbicide and CT adoption.

The model results suggest that if the influence of the farm location is excluded, there are six factors that affect the joint-decision to adopt the herbicide use and CT technologies at farm household level. These are: being a male headed household, being a member of a cooperative, the number of crops planted, the area planted, household ownership of a knap sack sprayer and lastly, the household access to information and advice on CA. Results suggests that being male-household household has a significant effect on the decision to jointly adopt both technologies and accounts for $3.7 \%$ more chance of jointly adopting both herbicide and CT technologies as opposed to being a female-headed household. The result means that in Zambia, male-headed small holder farmers, are more likely to jointly adopt both technologies than female headed household farmers. This could be reflecting the situation of most male headed households being well resource endowed than their female counterparts. Being a member of a cooperative society accounted for $3.16 \%$ more chance of jointly adopting both technologies as opposed to farmers who did not belong to a cooperative grouping. This result agrees with some earlier studies which found that smallholder farmers who belonged to farmer cooperatives were found to more easily adopt technologies, singularly or jointly than farmers who did not belong to any cooperative (Teklewold, 2005; Nzomoi, 2007; Uwaegbuonu, 2010; Arslan et al., 2013; Government of Canada, 2013). This outcome points to the fact that farmers need to belong to social capital networks for them to adopt technologies jointly, especially complementary ones.

The result suggests that for an additional crop planted in the season, the probability of jointly adopting herbicides and $\mathrm{CT}$ technologies increases by $0.3 \%$. This finding seems to suggest that farmers who diversify and grow more crops are likely going to find it easy to adopt agricultural technologies. The area planted by farmers accounted for $1.4 \%$ more probability of positively influencing joint-adoption decision of herbicides and CT methods. One explanation for this could be that farmers with larger farm sizes are likely to be well endowed in terms of resources and could therefore afford to embrace new technologies. Moreover, the larger the area a farmer cultivates, the more likely he is to use herbicides to control weeds as opposed to manual weeding. It follows that with the adoption of $\mathrm{CT}$ on a larger area, a farmer is likely to adopt herbicides as well to offset the drudgery of manual weeding and beat the narrow window period the season permits for weeding the larger crop fields. These results are consistent with findings by earlier researchers such as Chomba (2004), Arslan et al. (2013), and Ogada et al. (2014). 
Table 3. Factors determining adoption decisions of crop herbicides and/or CT technologies by smallholder farmers in Zambia

\begin{tabular}{|c|c|c|c|c|c|c|c|c|c|c|c|c|c|c|c|}
\hline \multirow[b]{2}{*}{ Variables } & \multicolumn{6}{|c|}{ Adoption of Crop Herbicides } & \multicolumn{6}{|c|}{ Adoption of Conservation Tillage Methods } & \multicolumn{3}{|c|}{ Joint Adoption } \\
\hline & Coef & $\begin{array}{l}\text { Robust } \\
\text { std. err. }\end{array}$ & $\begin{array}{l}\text { Sign. } \\
\text { lev. }\end{array}$ & $\begin{array}{l}\text { Margin } \\
\text { effect }\end{array}$ & $\begin{array}{l}\text { Std. } \\
\text { err. }\end{array}$ & $\begin{array}{l}\text { Sig. } \\
\text { lev. }\end{array}$ & Coef & $\begin{array}{l}\text { Robust } \\
\text { std. err. }\end{array}$ & $\begin{array}{l}\text { Sig. } \\
\text { lev. }\end{array}$ & $\begin{array}{l}\text { Margin } \\
\text { effect }\end{array}$ & $\begin{array}{l}\text { Std. } \\
\text { err. }\end{array}$ & $\begin{array}{l}\text { Sig. } \\
\text { lev. }\end{array}$ & $\begin{array}{l}\text { Margin } \\
\text { effect }\end{array}$ & $\begin{array}{l}\text { Std. } \\
\text { err. }\end{array}$ & $\begin{array}{l}\text { Sig. } \\
\text { lev. }\end{array}$ \\
\hline \multicolumn{16}{|c|}{ 1. Farmer Household Characteristics } \\
\hline Male head & 0.1222 & 0.0781 & & 0.0092 & 0.0055 & $*$ & -0.0333 & 0.0812 & & -0.0020 & 0.0049 & & 0.0372 & 0.02019 & $*$ \\
\hline No. Hhm Aged btn $15-59$ years & -0.0035 & 0.0227 & & -0.0003 & 0.0018 & & 0.0054 & 0.0271 & & 0.0003 & 0.0016 & & -0.0018 & 0.00641 & \\
\hline Primary education $=1(0 \mathrm{o} / \mathrm{w})$ & -0.1326 & 0.0871 & & -0.0109 & 0.0074 & & 0.2762 & 0.1140 & $* *$ & 0.0153 & 0.0061 & $* *$ & -0.0638 & 0.02784 & $* *$ \\
\hline Secondary $=1(0 \mathrm{o} / \mathrm{w})$ & -0.0197 & 0.0937 & & -0.0016 & 0.0075 & & 0.1337 & 0.1258 & & 0.0082 & 0.0081 & & -0.0191 & 0.02632 & \\
\hline College/Universit $=1(0 \mathrm{o} / \mathrm{w})$ & 0.2812 & 0.1324 & $* *$ & 0.0286 & 0.0164 & $*$ & 0.4293 & 0.1732 & $* *$ & 0.0362 & 0.0199 & $*$ & 0.0390 & 0.04161 & \\
\hline Member of a cooper $=1(0 \mathrm{o} / \mathrm{w})$ & 0.1142 & 0.0573 & $* *$ & 0.0093 & 0.0046 & $* *$ & -0.0023 & 0.0652 & & -0.0001 & 0.0037 & & 0.0316 & 0.01638 & $*$ \\
\hline $\begin{array}{l}\text { Member of credit Assoc }=1 \\
(0 \mathrm{o} / \mathrm{w})\end{array}$ & 0.0791 & 0.1153 & & 0.0068 & 0.0106 & & 0.0122 & 0.1388 & & 0.0007 & 0.0081 & & 0.0189 & 0.03297 & \\
\hline \multicolumn{16}{|l|}{ 2. Farm Characteristics } \\
\hline No. of Hh members (size) & 0.0040 & 0.0148 & & 0.0003 & 0.0012 & & 0.0028 & 0.0175 & & 0.0002 & 0.0010 & & 0.0009 & 0.00414 & \\
\hline No. of crops planted & 0.0748 & 0.0178 & $* * *$ & 0.0061 & 0.0015 & $* * *$ & 0.1305 & 0.0191 & $* * *$ & 0.0075 & 0.0011 & $* * *$ & 0.0090 & 0.00494 & $*$ \\
\hline Area planted (in $\mathrm{Ha}$ ) & 0.0465 & 0.0107 & $* * *$ & 0.0038 & 0.0009 & $* * *$ & -0.0148 & 0.0147 & & -0.0008 & 0.0008 & & 0.0140 & 0.00338 & $* * *$ \\
\hline Own k/sack sprayer $=1(0 \mathrm{o} / \mathrm{w})$ & 0.4595 & 0.0672 & $* * *$ & 0.0492 & 0.0094 & $* * *$ & 0.3336 & 0.0804 & $* * *$ & 0.0240 & 0.0071 & $* * *$ & 0.1055 & 0.02329 & $* * *$ \\
\hline Own cattle $=1(0 \mathrm{o} / \mathrm{w})$ & -0.0801 & 0.0679 & & -0.0063 & 0.0052 & & -0.1367 & 0.0811 & $*$ & -0.0075 & 0.0042 & $*$ & -0.0088 & 0.01877 & \\
\hline Distance to town centre $(\mathrm{km})$ & -0.0005 & 0.0012 & & 0.0000 & 0.0001 & & -0.0022 & 0.0013 & & -0.0001 & 0.0001 & & 0.0001 & 0.00034 & \\
\hline Distance to Agro-dealer (km) & -0.0009 & 0.0014 & & -0.0001 & 0.0001 & & -0.0028 & 0.0016 & $*$ & -0.0002 & 0.0001 & $*$ & 0.0000 & 0.00038 & \\
\hline $\begin{array}{l}\text { Distance to extension officer } \\
(\mathrm{km})\end{array}$ & -0.0003 & 0.0013 & & 0.0000 & 0.0001 & & -0.0017 & 0.0020 & & -0.0001 & 0.0001 & & 0.0001 & 0.0004 & \\
\hline \multicolumn{16}{|l|}{ 3. Institutional Factors } \\
\hline State Land tenure $=1(0 \mathrm{o} / \mathrm{w})$ & -0.0009 & 0.0917 & & -0.0001 & 0.0074 & & -0.1397 & 0.1151 & & -0.0071 & 0.0052 & & 0.0106 & 0.02565 & \\
\hline Receive CA Advice $=1(0 \mathrm{o} / \mathrm{w})$ & 0.2473 & 0.0646 & $* * *$ & 0.0196 & 0.0050 & $* * *$ & 0.1256 & 0.0724 & $*$ & 0.0071 & 0.0041 & $*$ & 0.0543 & 0.01791 & $* * *$ \\
\hline Import $\mathrm{CA}$ advise supplier & -0.0549 & 0.0361 & & -0.0044 & 0.0029 & & -0.0883 & 0.0450 & $* *$ & -0.0051 & 0.0026 & $* *$ & -0.0069 & 0.01012 & \\
\hline \multicolumn{16}{|l|}{ 4. Location of the Farm } \\
\hline Central province $=1(0 \mathrm{o} / \mathrm{w})$ & 1.1024 & 0.2573 & $* * *$ & 0.1838 & 0.0659 & $* * *$ & 0.8425 & 0.2686 & $* * *$ & 0.0925 & 0.0456 & $* *$ & 0.2983 & 0.09552 & $* * *$ \\
\hline Copperbelt province $=1(0 \mathrm{o} / \mathrm{w})$ & 1.2468 & 0.2624 & $* * *$ & 0.2359 & 0.0784 & $* * *$ & 0.7438 & 0.2752 & $* * *$ & 0.0794 & 0.0450 & $*$ & 0.3807 & 0.09981 & $* * *$ \\
\hline Eastern province $=1(0 \mathrm{o} / \mathrm{w})$ & 0.8774 & 0.2595 & $* * *$ & 0.1091 & 0.0439 & $* *$ & 0.7991 & 0.2615 & $* * *$ & 0.0716 & 0.0326 & $* *$ & 0.2027 & 0.08374 & $* *$ \\
\hline Luapula province $=1(0 \mathrm{o} / \mathrm{w})$ & 0.7476 & 0.2719 & $* * *$ & 0.1027 & 0.0540 & $*$ & 0.6125 & 0.2760 & $* *$ & 0.0576 & 0.0374 & & 0.1858 & 0.09632 & $*$ \\
\hline Lusaka province $=1(0 \mathrm{o} / \mathrm{w})$ & 1.1979 & 0.2728 & $* * *$ & 0.2301 & 0.0836 & $* * *$ & 1.0399 & 0.2803 & $* * *$ & 0.1443 & 0.0656 & $* *$ & 0.3198 & 0.10529 & $* * *$ \\
\hline Northern province $=1(0 \mathrm{o} / \mathrm{w})$ & 1.0159 & 0.2627 & $* * *$ & 0.1659 & 0.0659 & $* *$ & 0.9444 & 0.2646 & $* * *$ & 0.1149 & 0.0518 & $* *$ & 0.2524 & 0.09707 & $* * *$ \\
\hline Muchinga province $=1(0 \mathrm{o} / \mathrm{w})$ & 0.4142 & 0.2750 & & 0.0446 & 0.0374 & & 0.6489 & 0.2643 & $* *$ & 0.0613 & 0.0359 & $*$ & 0.0656 & 0.08278 & \\
\hline Southern province $=1(0 \mathrm{o} / \mathrm{w})$ & 0.6938 & 0.2617 & $* * *$ & 0.0879 & 0.0459 & $*$ & 0.4753 & 0.2738 & $*$ & 0.0387 & 0.0293 & & 0.1821 & 0.09038 & $* *$ \\
\hline Western province $=1(0 \mathrm{o} / \mathrm{w})$ & 0.8151 & 0.2734 & $* * *$ & 0.1184 & 0.0587 & $* *$ & 0.3679 & 0.2963 & & 0.0287 & 0.0298 & & 0.2458 & 0.10293 & $* *$ \\
\hline Constant & -3.0370 & 0.2952 & $* * *$ & & & & -2.8872 & 0.2836 & $* * *$ & & & & & & \\
\hline
\end{tabular}

Note. Significance levels: $\mathrm{p} \leq 1 \%=* * *, \mathrm{p} \leq 5 \%=* *, \mathrm{p} \leq 10 \%=*$.

Sample siz e $=8839$.

Owning a knapsack sprayer, which is a productive tool, has a profound and positive impact on technology adoption. It accounted for $10.55 \%$ more chances of adopting the herbicide and CT jointly by a farmer. In the joint-adopter category, over half of the farmers $(53.6 \%)$ owned knapsack sprayers. The percentage of non-adopter farmers who owned sprayers was only $14.6 \%$. This outcome implies that in the context of smallholder farming, an agricultural tool like a knapsack sprayer is important for both herbicide and CT adoption decision. This is probably because possessing one is a motivation to use herbicides rather than to rely on hand weeding, borrowing or renting one. In fact, households that adopt herbicides and CT methods also have more economically active family members (with age range of 15 to 59 years) as can be seen in Table 2 . This means that they have slightly more labor available for herbicide application and $\mathrm{CT}$ technologies adoption than non-adopters, who have relatively fewer economically active family sizes. The result implies that a productive tool like a sprayer is indispensable, if a farmer has to adopt one of the two technologies or jointly adopt both. This outcome is similar to the findings of Rahman (2008) and Ngoma (2010). 
Receiving advice from the extension services plays a major role in the farmers' technology adoption. A farmer who received CA advice had 5.4\% more chances of jointly adopting both herbicides and CT technologies than the one who did not receive any advice at all. This positive outcome of farmers' receipt of CA advice underpins the critical role extension services play in adoption of agricultural technologies in the country. This result is important for a country like Zambia, where technology adoption such as herbicides are still relatively low. The repercussions on food security are far-reaching, in the long-term, should this low technology adoption trend continue. This outcome is similar to that of Matthews and Clayton (1999). In Nigeria, Uwaegbuonu (2010) found similar results. Egyir (2010) in Ghana arrived at identical results. In Zambia, Ngoma (2010) discovered the importance of giving farmers advice on herbicide application methodologies by the Extension Services wing. The more the farmers were privileged to learn about herbicides and got information, the more was the adoption of the same amongst them.

It can be seen that the spatial location of farms has much higher and stronger positive influence on the technology adoption decision than many other variables under the joint adoption category (Table 3 ). In fact, the farm location alone, as a variable, is a single major and significant factor explaining the adoption of either herbicide or CT. This is evident, from all the provinces, except Muchinga, where it is not significant. The likelihood of joint-technologies' adoption relative to Northwestern province was $38.07 \%, 31.98 \%$ and $29.83 \%$ on the Copperbelt, Lusaka and Central provinces respectively. One possible and empirical explanation of this observation is that the more developed infrastructural and institutional frameworks that exist in more urbanized provinces are responsible for these higher adoption percentages. Accessibility to agricultural service providers is another major factor. It can be argued, for example that there are more established agro-dealers in more urbanized areas, particularly along the line of rail, than in many outlying areas like the Luapula and Northwestern provinces. Institutional factors such as crop marketing and agricultural information flow are also easy to access in urban areas than in rural places. In addition, extension services are relatively more accessible in urbanized areas and farmers in these places frequently share knowledge, because farms are in close proximity than is the case in rural settings. When it comes to socioeconomic factors, relatively more educated farmer settlers and retired public servants are concentrated in these urbanized provinces of Copperbelt, Central and Lusaka. These factors explain the observed high joint-adoption rates in these provinces. The single technology adoption rates observed in Central and Copperbelt are in agreement with Mbazima (1997). Northern, Western and Eastern provinces also have relatively high joint-adoptions. Again, the possible explanation for this is that there are relatively well-established extension systems in these areas. In addition, the same areas have comparatively higher agricultural potential, which attract various agricultural stakeholders. The location of the farm and its importance has been documented in earlier and similar studies such as that of La Rovere et al. (2000), Kizito et al. (2009), and Egyir (2010).

\section{Conclusions and Recommendations}

The study found that among smallholder farmers in Zambia, the decision to adopt crop herbicides and conservation tillage methods is jointly made. Therefore, promoting conservation tillage technology would implicitly promote the uptake of herbicides in smallholder farming communities. Among smallholder farmers of Zambia, being a male-headed household implies more potential to jointly adopt herbicides and CT technologies than being a female-headed household. This shows that in this country, female-headed households may be resource-constrained as opposed to their male counterparts. Belonging to a cooperative society, increases the chance of jointly adopting both herbicides and CT technologies. It is concluded that cooperatives are platforms where smallholder farmers share latest agricultural technologies and innovations. They are conduits that encourage and boost smallholder agricultural innovation adaptation and adoption. This emphasizes the importance of social capital in technology adoption. At farm level, owning a productive tool like a knapsack sprayer is an important contributor to joint-adoption of herbicides and CT methods. Herbicide use is one of the labor-saving technologies. In labor-intensive production technologies such as CT, herbicides are indispensable. It follows that to implement either herbicides or CT or both, successfully, a farmer has to use a sprayer. For smallholder farmers, CA advice, through extension services, is an effective instrument in promoting herbicide and CT technology adoption. More urbanized regions or provinces were more likely to adopt herbicides and CT methods.

There is therefore need for stakeholders and partners working towards uplifting smallholder farmers' productive capacity, through herbicide and CT technology adoption to focus on the roles played by gender, social capital, farm characteristics and the spatial location of the farm. The field extension services must intensify the promotion and dissemination of information on herbicides and CT methods. Preferably, farmers should be encouraged to belong to more organized social groups such as being members of vibrant agricultural cooperatives. This gesture could make dissemination efforts more successful. Lastly, information from the study revealed that smallholder farmers whose farms are in more urbanized areas were found to jointly adopt herbicides and CT technologies more than 
those in outlying areas. The inference from this is that farmers in urban areas have easier access to inputs such as herbicides because the commodity markets are within reach. This is not the case with more distant and rural farm settings. In urban areas, there is a dense networks of agro-dealers. In addition, they are in closer proximity with information sources such as media outlets like radios, television and from well-informed extension staff. It follows that development of good roads and other relevant infrastructure may help in smallholder farmers' easier adoption of these technologies.

\section{References}

Abay, K. A., Berhane, B. G., Seyoum, T. A., Koru, B., \& Abay, K. (2016). Understanding farmers' technology adoption decisions: Input complementarity and heterogeneity. ESSP Working Paper 82. Washington, D.C. and Addis Ababa, Ethiopia: International Food Policy Research Institute (IFPRI) and Ethiopian Development Research Institute (EDRI). Retrieved from http://ebrary.ifpri.org/cdm/ref/collection/p15738 coll2/id/130163

Adesina, A. A. (1996). Factors affecting the adoption of fertilizer by rice farmers in Cote d'Ivoire. Nutrient Cycling in Agro-Ecosystems, 46(1), 29-39. https://doi.org/10.1007/BF00210222

Adesina, A. A., \& Zinnah, M. M. (1993). Technology characteristics, farmers' perspectives and adoption decisions: A Tobit model application in Sierra Leone. Agricultural Economics, 9(4), 297-311. https://doi.org/10.1016/0169-5150(93)90019-9

Arslan, A., Lipper, L., Asfew, S., \& Cattaneo, A. (2013). Adoption and Intensity of Adoption of Conservation Farming Practices in Zambia. ESA Working Paper No. 13-01. Food and Agriculture Organization, Agricultural Development Economics Division. Retrieved from http://www.fao.org/3/a-aq288e.pdf

Beltran, J., White, B., Burton, M., Doole, G., \& Pannell, D. (2013). Determinants of herbicide use in rice production in the Philippines. Agricultural Economics, 44(1), 45-55. https://doi.org/10.1111/j.1574-0862. 2012.00631.x

Bryan, E., Deressa, T., Gbetibouo, T., \& Ringler, C. (2009). Adaptation to climate change in Ethiopia and South Africa: strategies and constraints. Journal of Environmental Science and Policy, 12(4), 413-426. https://doi.org/10.1016/j.envsci.2008.11.002

Central Statistics Office (CSO). (2014). 2011/2012 Post-harvest survey. CSO, Lusaka, Zambia. Retrieved from http://www.zamstats.gov.zm/index.php/publications/category/12-agriculture

CFU. (2007). Conservation Farming and Conservation Agriculture Handbook for Hoe Farmers in Agro-Ecological Regions I and IIa. Retrieved from http://www.fsnnetwork.org/sites/default/files/ conservation_farming_handbook.pdf

Chikoye, D., Ellis-Jones, J., Riches, C., \& Kanyomeka, L. (2007a). Weed management in Africa: Experiences, challenges and opportunities (pp. 652-653). XVI International Plant Congress.

Chikoye, D., Schultz, S., \& Ekeleme, F. (2004). Evaluation of integrated weed management practices for maize in the Northern Guinea savanna of Nigeria. Crop Protection, 23(10), 895-900. https://doi.org/10.1016/ j.cropro.2004.01.013

Chikoye, D., Udensi, U. E., Lum, A. F., \& Ekeleme, F. (2007b). Rimsulfuron for post emergence weed control in corn in humid tropical environments of Nigeria. Weed Technology, 21(4), 977-81. https://doi.org/10.1614/ WT-07-032.1

Chirwa, W. E. (2005). Adoption of fertilizer and hybrid seeds by smallholder maize farmers in Southern Malawi. Development Southern Africa, 22(1), 1-12. https://doi.org/10.1080/03768350500044065

Chomba, N. G. (2004). Factors Affecting Smallholder Farmers' Adoption of Soil and Water Conservation Practices in Zambia (Master of Science in Agricultural Economics Thesis, Michigan State University). Retrieved from http://fsg.afre.msu.edu/zambia/chomba_thesis_updated_version.pdf

De Souza Filho, H. M., Young, T., \& Burton, M. P. (1999). Factors influencing adoption sustainable agricultural Technologies: Evidence from the state of Espirito Santo, Brazil. Technological Forecasting and Social Change, 60(2), 97-112. https://doi.org/10.1016/S0040-1625(98)00040-7

Egyir, S. I. (2010). Assessing the Factors of Adoption of Agro-chemicals by Plantain Farmers in Ghana Using the ASTI Analytical Framework. Retrieved from http://www.africa-platform.org/sites/default/files/ resources/assessing_the_factors_of_adoption_of_agro-chemicals_by_plantain_farmers_in_ghana.pdf 
FAO. (1996). Women Feed the World in World Food Summit Food for All, Rome, November 13-17, 1996. Retrieved from http://www.fao.org/docrep/x0262e/x0262e16.htm

FAO. (2011). The State of food Insecurity in the world. How does international price volatility affect domestic economies and food security? Retrieved from http://www.fao.org/docrep/014/i2330e/i2330e.pdf

FAO. (2013). Country profile: Zambia. Retrieved from http://www.fao.org/countryprofiles/index/en/?iso3=ZMB

Forum for Agricultural Research in Africa (FARA). (2006). Framework for African Agricultural Productivity. Retrieved from http://faraafrica.org/wp-content/uploads/2015/04/FAAP_English.pdf

Gabre-Madhin, E., \& Johnston, B. (1999). Accelerating Africa's Structural Transformation: Lessons from Asia. In T. S. Jayne, M. Isaac, \& A.-K. Gem (Eds.), Perspectives on Agricultural Transformation: A View from Africa. Nova Science, New York. Retrieved from http://purl.umn.edu/97383

Gianessi, L., \& Williams, A. (2011). Overlooking the Obvious: The Opportunity for Herbicides in Africa. Retrieved from https:/croplifefoundation.org/wp-content/uploads/2015/12/overlooking-the-obvious.pdf

Golden Valley Agricultural Research Trust (GART). (2002). Accelerated transfer of conservation farming technologies: A concept note. Lusaka: GART.

Government of Canada. (2013). Factors Affecting the Adoption of Agricultural Beneficial Management Practices. Retrieved from http://www.agr.gc.ca/resources/prod/doc/prog/WEBs_EPBH_BMP_PGB2012_eng.pdf

Government of the Republic of Zambia. (2004). National Agriculture Policy (2004-2015). Retrieved from http://www.gafspfund.org/sites/gafspfund.org/files/Documents/5.\%20Zambia_strategy.pdf

Government of the Republic of Zambia. (2006). Fifth National Development Plan. Retrieved from http://www.mcti.gov.zm/index.php/downloads/doc_download/4-fndp

Grabowski, P. P., Kerr, J. M., Haggblade, S., \& Kabwe, S. (2014). Minimum tillage adoption among commercial smallholder cotton farmers in Eastern Zambia. Working Paper No. 87. Indaba Agricultural Policy Research Institute (IAPRI). Retrieved from http://ageconsearch.umn.edu/bitstream/188567/2/wp87.pdf

Greene, W. H. (2003). Econometrics Analysis (4th ed.). New Jersey: Pearson Education, Inc.

Haggblade, S., \& Tembo, G. (2003). Early Evidence on Conservation Farming in Zambia. Paper presented at the Conference: "Reconciling Rural Poverty and Resource Conservation: Identifying Relationships and Remedies" held at Cornell University, May 2-3, 2003. Ithaca, NY: Cornell University. Retrieved from https://vtechworks.lib.vt.edu/bitstream/handle/10919/68475/4237_Haggblade_Tembo.pdf?sequence=1\&isA llowed=y

Haggblade, S., \& Tembo, G. (2003a). Conservation Farming in Zambia. EPTD. Discussion Paper 108. Washington D.C., International Food Policy Research Institute (IFPRI). Retrieved from http://www.fao.org/ docs/eims/upload/166322/haggblade,tembo.pdf

Kalineza, H. M. M., Mdoe, N. S. Y., \& Mlozi, M. R. S. (1999). Factors Influencing Adoption of Soil Conservation Technologies in Tanzania. A Case Study in Gairo. Retrieved from www.tzonline.org/pdf/ factorinfluencingadoptionofsoil.pdf

Kassie, M., Jaleta, M., Shiferaw, B., Mmbando, F., \& Mekuria, M. (2013). Adoption of interrelated sustainable agricultural practices in smallholder systems: Evidence from rural Tanzania. Technological Forecasting and Social Change, 80(3), 525-540. https://doi.org/10.1016/j.techfore.2012.08.007

Knowler, D., \& Bradshaw, B. (2007). Farmers' Adoption of Conservation Agriculture: A Review and Synthesis of Recent Research. Food Policy, 32(1), 25-48. https://doi.org/10.1016/j.foodpol.2006.01.003

La Rovere, R., Tsegaye, W., Aredo, D., Mwangi, W., Kassie, G. T., \& Mwabu, G. (2000). Adoption and Impact of Conservation Agriculture in Central Ethiopia. CIMMYT, Ethiopia.

Maddala, G. (1983). Limited-Dependent and Qualitative Variables in Econometrics. Cambridge: Cambridge University Press. https://doi.org/10.1017/CBO9780511810176

Matthews, G. A., \& Clayton, J. S. (1999). The potential of low volume Herbicide application in developing agriculture. Proceedings of the 1999 Brighton Conference-Weeds (pp. 379-384).

Mbazima, K. M. (1997). Factors Affecting the Use of Herbicides in Small and Medium Maize Production. The Case of Copperbelt and Central Provinces of Zambia (M.B.A. Dissertation, The Copperbelt University). Retrieved from http://dspace.cbu.ac.zm:8080/jspui/bitstream/123456789/146/1/MBAZIMA,\%20M.\%20K 
NOX0001\%20-\%20Factors\%20affecting\%20the\%20adoption $\% 20$ of $\% 20$ the $\% 20$ use $\% 20$ of $\% 20$ herbicides $\%$ 20 in $\% 20$ small $\% 20$ and $\% 20$ medium $\% 20$ scale $\% 20$ maize $\% 20$ production.PDF

Ministry of Agriculture, Food and Fisheries (MAFF). (2001). MAFF Annual Report. Lusaka.

Mohammad, K., \& Noor-ul, H. (2004). Weed control in maize (Zea mays L.) with pre and post-emergence herbicides. Pak. J. Weed Sci. Res., 10(1-2), 39-46. Retrieved from http://agris.fao.org/agris-search/ search.do? recordID=PK20050001033

Mwangi, M., \& Kariuki, S. (2015). Factors Determining Adoption of New Agricultural Technology by Smallholder Farmers in Developing Countries. Journal of Economics and Sustainable Development, 5(6), 208-216. Retrieved from http://www.iiste.org/Journals/index.php/JEDS/article/viewFile/20710/21632

Nayga, R. M. (1996). Sociodemographic influences on consumer concern for food safety: The case of irradiation, antibiotics, hormones, and pesticides. Review of Agricultural Economics, 18(3), 467-475. https://doi.org/ $10.2307 / 1349629$

Neill, S. P., \& Lee, D. R. (1999). Explaining the Adoption and Disadoption of Sustainable Agriculture: The Case of Cover Crops in Northern Honduras. Working Paper. Retrieved from http://publications.dyson.cornell. edu/research/researchpdf/wp/1999/Cornell_Dyson_wp9931.pdf

Ngoma, H., Mulenga, B. P., \& Jayne, T. S. (2014). What Explains Minimal Usage of Minimum Tillage Practices in Zambia? Evidence from District Representative Data. Working Paper No. 82. Indaba Agricultural Policy Research Institute (IAPRI), Lusaka, Zambia. Retrieved from http://fsg.afre.msu.edu/zambia/wp82.pdf

Ngoma, P. (2010). Success Story-Training: Spray Service Providers' Programme. Crop Life Zambia, Hub Meeting East and Southern Africa, August 24-25, 2010, Dar-es-Salaam, Tanzania.

Nkamleu, G. B., \& Adesina A. A. (2000). Determinants of chemical input use in peri-urban lowland systems: Bivariate Probit Analysis in Cameroon. Agricultural Systems, 63, 111-121. Retrieved from https://pdfs.semanticscholar.org/34bf/c44128e779a55f33debe676b286f2b0eaace.pdf

Nkegbe, K. P., Bhavani, S., \& Graziano, C. M. (2011). Smallholder adoption of Soil and Water conservation practices in Northern Ghana. EAAE 2011 Congress Paper. ETH Zurich, Switzerland. Retrieved from http://ageconsearch.umn.edu/bitstream/114608/2/Nkegbe_Paul_347.pdf

Nyanga, P. H. (2012). Factors influencing adoption and area under conservation agriculture: A case mixed method approach. Sustainable Agriculture Research, 1(2), 27. https://doi.org/10.5539/sar.v1n2p27

Nzomoi, J. N., Byaruhanga, J. K., Maritim, H. K., \& Omboto, P. I. (2007). Determinants of technology adoption in the production of horticultural export produce in Kenya. Sustainable Agricultural Research. African Journal of Business Management, 1(5), 129-135. Retrieved from https://www.researchgate.net/publication/ 228402554_Determinants_of_Technology_Adoption_in_the_Production_of_Horticultural_Export_Produce in_Kenya

Ogada, M. J., Mwabu, G., \& Muchai. (2014). Farm technology adoption in Kenya: A simultaneous estimation of inorganic fertilizer and improved maize variety adoption decisions. Agricultural and Food Economics. Retrieved from https://pdfs.semanticscholar.org/97f7/8678801c9d837c57a4c4e15974aab4008ce6.pdf

Rahman, S. (2008). Determinants of crop choices by Bangladeshi farmers: A bivariate probit analysis. Asian Journal of Agriculture and Development, 5(1), 30. Retrieved from http://ageconsearch.umn.edu/bitstream/ 198978/2/AJAD_2008_5_1_2Rahman.pdf

Teklewold, H., Kassie, M., \& Shiferaw, B. (2005). Adoption of multiple sustainable practices in rural Ethiopia. Retrieved from http:/www.economics.handels.gu.se/digitalAssets/1374/1374445_120621-teklewold-ppr 4.pdf

Thapa, S. (2008). Adoption of improved seeds and inorganic fertilizers in Nepal. CIFREM, University of Trento, Nepal. Retrieved from http://www.unitn.it/files/download/11007/en_full_paper_17_07_2008.pdf

Uwaegbuonu, O. I. (2010). Determinants of adoption of new technologies and the role of credit in production of rice in Benue State, Nigeria. Agricultural Journal, 5(4). https://doi.org/10.3923/aj.2010.264.268

Wainaina, P., Tongruksawattana, S., \& Quaim, M. (2014). Tradeoffs and complementary in the adoption of improved seeds, Fertilizer and natural management technologies in Kenya. Global food Discussion Paper. Georg-August-University of Gottingen, Germany. Retrieved from https:/www.econstor.eu/bitstream/10419/ 104815/1/805619127.pdf 
Zulu, M., Mukata, W., \& Mugisha, J. (2008). Socio-economic analysis of land management practices in the agricultural highlands of Uganda: A case of Kabale highlands. Retrieved from http://www.mocu.ac.tz/ upload/researches/MUNGISHA\%20 ZULU\%20AND\%20\%20WAMULUME-1.pdf

\section{Copyrights}

Copyright for this article is retained by the author(s), with first publication rights granted to the journal.

This is an open-access article distributed under the terms and conditions of the Creative Commons Attribution license (http://creativecommons.org/licenses/by/4.0/). 